\title{
LITERACY'S FEEDBACK ON HISTORICAL ANALYSIS REVISITED: PAPERS IN HONOR OF DAVID HENIGE
}

\author{
MiChEL R. DOORTMONT, UNIVERSITY OF GRONINGEN
}

JOHN H. HANSON, INDIANA UNIVERSITY

JAN JANSEN, LEIDEN UNIVERSITY

DMitri van den BersselaAr, University of Liverpool

During the course of a long and fruitful career as an historian and librarian, David Henige has made major contributions to the development of the field of African history, as well as to the historical profession in general. His insistence that historians reflect carefully on how they collect, sample and analyze their data, and the lucid way in which he has written about the historian's craft, has not only helped to remind us historians of important methodological concerns, it has also inspired us to engage with methodology as an exciting topic in its own right. One major theme in his work has been that of literacy and its impact on oral tradition, memory, and historical interpretation. His book Oral Historiography (1982) and his articles on "feedback" and chronology in oral tradition have become essential reading for all students of African history. While among historians of Africa, it is particularly in this area where he has made most if an impact, David Henige has also made important contributions to other fields of history. He is a remarkably versatile and widely read historian, who has engaged with an impressively broad range of topics - and in each case with a strong method- 
ological concern. ${ }^{1}$ His wide-ranging oeuvre and impact are explored in detail in Michel Doortmont's contribution to this special issue.

In 2009, when we decided to organize a panel in honor of David Henige for the 2010 Annual Meeting of the African Studies Association, it seemed nevertheless appropriate to focus on the theme for which he has become most well-known amongst historians of Africa. We thus invited colleagues to explore, on the basis of their own research, how literacy-related premises have worked on the level of historical method, and which consequences this has had for historical analysis. The response was overwhelming: the proposed panel had to become a double panel to accommodate more of the proposed papers, and it was sponsored by the ASA Board of Directors. After the ASA appointed us Henige's successors as editors of History in Africa, in January 2010, we decided to make the papers from this panel the basis for this special issue in his honor. We consider this particularly fitting, as David Henige was the founder of History in Africa. A Journal of Method in 1974, and remained its sole editor until the 2009 volume.

We decided to organize the present issue in three sections: first, an article by Doortmont, which reflects on David Henige's career and his impact on the discipline of history. This is followed by the second section, a selection of papers inspired by David Henige's work on the interplay between literacy, orality and historiography. The third section, with four papers on African archives, addresses some of his key concerns.

\section{II}

For the second section, the longest, we decided to continue in the tradition of Henige's editorship and publish these articles in alphabetical order, but we also see several thematic connections between the papers. Some papers reflect on how orality and literacy interact in African historical traditions. Cinnamon's contribution traces genealogical connections between anthropological fieldwork, terrains of oral and written history, and the production

\footnotetext{
${ }^{1}$ Having worked with David in the past years more intensively than before, the editors have become impressed by David's achievements which go far beyond African studies. They knew David as the journal's editor and as the bibliographer of African Studies at the University of Wisconsin-Madison's Memorial Library. What they didn't know was that these "African" activities were only part of his accomplishments. His track record to date gives hundreds of articles and reviews related to, next to African studies, academic fields such as education, archiving, philosophy of history, and library studies. For details, please see his CV on http://pcwww.liv.ac.uk/ dvdb/CV_Henige.pdf.
} 
of Gabonese ethnographic and historical memory. It shows that when professional fieldworkers arrived in Gabon after the Second World War, they encountered a late-colonial situation in which the villagers from whom they sought to record oral histories of pre-colonial society and colonial ruptures had been marked by repeated cycles of administrative, missionary, and Gabonese texts, cycles that included both oral and written phases. Cinnamon elucidates reciprocal influences and multiple traces of oral and written traditions on anthropological and historical knowledge production. Jansen's contribution explores one of the consequences of the fact that literacy skills are often taught in combination with a particular perspective on history, analyzing a number of cases whereby individuals experience their historical knowledge about Sunjata - taught in literacy training as well as by local family education - as so convincing that they relate it as evidence in support of a land claim that meets the State's demands of land registry, thus demonstrating how feelings of belonging to a nation are produced on a local level. In Holsey's contribution, the interaction between school education, nationalist thought, written (local) histories and European written sources, and the impact of this interaction on local oral traditions, is explored in detail for Elmina. The Ghanaian coastal town of Elmina was also the location for David Henige's work on kingship and kinglists and on feedback in oral tradition. However, while Henige explored the use of written sources in the creation of political strategies, Holsey's contribution argues that historians should also pay attention to the political aims within written sources themselves. Not only is there a back and forth between the oral and written traditions, but also, both have political concerns. Holsey shows how the political concerns of the Elmina residents' use of the story of Kwamena Ansa have included nationalism and resistance against economic marginalization, but also a response to the association of Elmina with the transatlantic slave trade, an association that was institutionalized through UNESCO's designation of Elmina as a World Heritage site.

In some cases it is not very clear which is the literary source at the basis of a present-day local tradition. In other cases it is, but that does not make it more transparent or easier to analyze, as is demonstrated by Donald Wright in his article on the impact of Roots on Gambian representations of the slave trade. Years ago, History in Africa published Wright's critical analysis of the Kunte Kinte traditions on which Alex Haley based his million-selling novel. Wright's study of "twenty years after" included here, shows that this academic historian's perspective has had no impact at all on local reimaginations which continue to magnify Kunte Kinte and increase the oral data 
relating to him. Whereas oral traditions represented in written history sometimes are the source of production of intangible heritage, in other cases contemporary texts may provide for an authentic basis of inspiration for recently defined groups. This is the case in Mack's analysis of Nana Asma'u's instruction of poetry for present-day American moslimahs.

Several papers explore the interaction between literacy and orality in more recently produced written materials, where the impact of orality might easily be overlooked, or where oral history can be used to draw further information or perspectives from the materials. Van den Bersselaar's contribution evaluates the use of company in-house magazines read alongside interviews with former employees as a source of information about the lives, careers and work experiences of African employees of European businesses during the colonial and postcolonial period. It argues that to focus on this group is important because these African employees domesticated capitalism in West Africa, mediated changes in consumption and the rise of a consumer society, and adopted European expectations of career progression and life cycle. These employees have much in common with the African intermediaries of "colonialism from the middle," discussed in Austen's contribution. Austen reports on his decade-long struggle to reconstruct the historical facts behind Amadou Hampâté Bâ's character Wangrin, which may shed light on the position of African clerks as well as the impact they sometimes have had on the production of histories of ethnic groups.

Roberts' exploration of work at the Korle Bu hospital in Accra from the 1920 s to $1970 \mathrm{~s}$, focuses on a novel documentary source, the Golden Jubilee Souvenir (1973). Reading this unusual source - part souvenir, part history, and part collective memory - alongside interviews with employees, the article explores nostalgic, and also rather less than romantic, employee memories of the Korle Bu hospital. A classical problem with literacy is that it produces sources that are still there but whose existence is forgotten over time. The historian's challenge is to locate them and to use them to open up new perspectives. McCaskie illustrates this problem with a study of Asante history for which he recently "discovered" a crucial Twi source... in his own collection of research data! It is likely that this source in Twi will shed much light on Asante histories published in English before 1940.

Kaufmann's evaluation of the terms and concepts used to understand Madagascar's cactus pastoralists, focuses on the balance between argumentation and evidence in historians' writing - one of David Henige's crucial methodological concerns. It considers how an academic historian may relate the terms and understandings of informants to the broader and more abstract 
concepts favored in historians' theories. The title of Twaddle's contribution, which promises to study "some implications of literacy" in Uganda, is a serious understatement. Taking the narrative of Twaddle's personal career as starting point, this article emphasizes the merits of prolonged fieldwork with intensive "rapport" with people represented as "informants." It argues that a historian of Africa is by definition obliged to take position in language politics. However, it also shows how the historian may be easily seduced to classify as "oral" and "authentic" informants who are, on a closer look, influenced by particular forms of literacy. That scholars cannot avoid to take position in issues of literacy production is the argument of Brizuela-Garcia, who explores the impact of debates among historians as to whether the work produced in Africa by literate groups can be considered "African," focusing on Arabic sources, and nineteenth century cultural nationalism. It shows how debating the "Africanness" of sources produced by literate groups resulted in the essentialization of African historical experiences, missed the opportunity to examine how literacy became an integral part of the African past, and offered a simplistic understanding of what a decolonized African history could be.

\section{III}

The third section, on African archives, fits very well in the broader theme of literacy and historical analysis as it shows African manuscripts to belong to the oral domain as well as to that of the written and read. This cluster of papers emerged out of a process of collaboration between two archive-centered projects, the Tombouctou Manuscripts Project and the Archive and Public Culture Research Initiative, with scholars from distant parts of the continent, and often separate scholarly traditions and milieus, now in direct communication with each other in an effort to think in new ways about archive. Work within the two projects draws attention to the kinds of complex trans-national and even trans-continental historical processes that give rise to archival collections. Often not recognized, Africa's long and deep tradition of writing and written records is powerfully attested to by the various Timbuktu manuscript collections and the Cape Town ajami tradition. Where former South African president, Thabo Mbeki's investment in a new archive building for Timbuktu was driven by an anxiety about the absence of archive on the continent, these four papers are redolent with senses of the 
density of archive of the continent, and the demands it exerts for scholarly engagement.

The circulation of ideas, words and texts features in all four of the papers. While the fluidity of oral texts has long been recognized and been the object of much scholarly attention, documents, seemingly by way of contrast, are often regarded as a frozen form, further stabilized by the fixative procedures of archive. Jeppie's paper alerts us to how copying in Timbuktu creates an archive within conditions of circulation - a move which on first pass may seem counter-intuitive, for an archive usually demands an "original" that is taken out of circulation. The papers by Jappie and Hamilton show that the written texts are not as settled as they may seem, often living active lives, changing things "out there" and being changed themselves, in processes over time. Jappie's paper address the ajami manuscript tradition of the Muslim community in Cape Town, tracing their social lives from their production in the nineteenth century to their use in contemporary South African heritage practices. Looking at manuscripts in motion, Jappie tracks transitions in status and form of the ajami across the domains of the oral, the written and read, and as material objects. Hamilton's paper usefully mobilizes the concepts of "backstory" and "biography" to distinguish between the circumstances and factors that shape ideas and texts before they enter an archive, and those that are at play once an archive is constituted. Her argument, made with reference to one particular archive, the James Stuart Archive, highlights the kinds of dynamic relationships that are in play over time between archives, scholarly knowledge and political discourses. Wright's paper investigates the role of one of colonial official James Stuart's chief interlocutors, Ndukwana kaMbengwana, in the making of the James Stuart Archive. The paper gives an indication of the depth of detailed scholarship needed for researchers to begin to grapple with the full range of factors that shape written records in the archive. Taken together, the four papers in this section signal a new methodological turn in their concern with the conditions of the ongoing production of archives. 